\title{
Implementasi Data Mining Dengan Algoritma Multiple Linear Regression Untuk Memprediksi Penyakit Diabetes
}

\author{
Ratih Yulia Hayuningtyas ${ }^{1}$, Retno Sari ${ }^{2}$ \\ ${ }^{1,2}$ Universitas Nusa Mandiri \\ ${ }^{1}$ ratih.ryl@ nusamandiri.ac.id \\ ${ }^{2}$ retno.rnr@ nusamandiri.ac.id
}

\begin{abstract}
Abstrak - Menurut WHO diabetes merupakan gangguan metabolisme yang ditandai dengan tingginya kadar gula dalam darah. Diabetes merupakan penyakit yang mematikan apabila penderita tidak bisa mengendalikannya dan akan menjadi komplikasi. Banyak orang yang terkena penyakit diabetes dan terlambat mengetahuinya, sehingga pada saat melakukan pengobatan kondisi sudah komplikasi. pendeteksian penyakit diabetes sejak dini sangat membantu bagi penderita untuk menghindari adanya komplikasi yang akan terjadi. Maka dari itu dibutuhkan suatu teknik data mining yang dapat mengolah data dan mencegah penyakit diabetes sejak dini. Data mining merupakan suatu proses penggalian pengetahuan dari sejumlah data untuk menemukan sebuah pola. Data mining sudah banyak digunakan salah satunya tentang metode prediksi untuk mengetahui penderita diabetes. Banyak sekali metode prediksi yang ada, salah satunya linear regression, dimana metode ini menggunakan atribut dependen dan independen. Dalam penelitian ini menggunakan metode multiple linear regression untuk memprediksi penyakit diabetes, serta melakukan evaluasi menggunakan RMSE (root mean square error). Hasil dari penelitian ini menghasilkan nilai RMSE sebesar 0.403, pengujian RMSE menggunakan cross validation dengan mengubah nilai number of validation.
\end{abstract}

Kata Kunci: Data Mining, Linear Regression, Diabetes

Abstract - According to WHO, diabetes is a metabolic disorder characterized by high levels of sugar in the blood. Diabetes is a deadly disease if the sufferer cannot control it and it will become a complication. Many people are affected by diabetes and find out too late, so that at the time of treatment the condition has complications. Early detection of diabetes is very helpful for sufferers to avoid complications that will occur. Therefore we need a data mining technique that can process data and prevent diabetes from an early age. Data mining is a process of extracting knowledge from a number of data to find a pattern. Data mining has been widely used, one of which is the prediction method to find out people with diabetes. There are so many prediction methods available, one of which is linear regression, where this method uses dependent and independent attributes. In this study, the multiple linear regression method is used to predict diabetes, and evaluates using RMSE (root mean square error). The results of this study produce an RMSE value of 0.403, the RMSE test uses cross validation by changing the number of validation value

Keywords: Data Mining, Linear Regression, Diabetes

\section{PENDAHULUAN}

Diabetes merupakan penyakit yang menyebabkan kematian terbesar no 3 di Indonesia dengan jumlah persentase $6,7 \%$, setelah stroke $(21,1 \%)$ dan jantung koroner $(12,9 \%)$ dan berdasarkan International Diabetes Federation (IDF) Atlas tahun 2017 Indonesia menduduki peringkat ke
6 (Lindungi Keluarga Dari Diabetes - Direktorat P2PTM, n.d.). Diabetes merupakan gangguan metabolisme didalam tubuh, dimana penyakit ini membuat tubuh menjadi resisten terhadap insulin sehingga insulin yang dihasilkan tidak berfungsi secara normal (Rahimloo \& Jafarian, 2016).

Salah satu faktor penyebab diabetes terlihat dari kebiasaan dan pola makan yang tidak benar

http://ejournal.bsi.ac.id/ejurnal/index.php/jtk 
seperti kurang berolahraga, merokok, makan makanan berprotein tinggi dan makanan siap saji (Baiju \& Aravindhar, 2019) selain itu biasanya ada faktor dari keluarga.

Diabetes sendiri memiliki dampak terhadap orang yang terkena seperti kerusakan vascular radio (Putri et al., 2021) selain itu dalam waktu lama diabetes menjadi komplikasi seperti serangan jantung, stroke, kerusakan mata, amputasi terhadap anggota tubuh yang terkena, bahkan kerusakan ginjal dan masih banyak lagi (Islam et al., 2019).

Dalam sepuluh tahun terakhir penyakit diabetes meningkat dua kali lipat di seluruh dunia dan sekitar 200 juta orang terkena penyakit diabetes (Rahimloo \& Jafarian, 2016). Salah satu penyebab meningkatnya jumlah penderita diabetes yaitu terlambat dalam mendiagnosa penyakitnya (Putri et al., 2021).

Diagnosis medis merupakan hal penting yang digunakan untuk memprediksi secara akurat, tetapi diagnosis medis tidak selalu mengetahuinya sehingga terlambat dalam mendeteksi penyakit diabetes. Deteksi dini sangat membantu untuk mengurangi terjadinya komplikasi, dalam pendeteksian dini diperlukan sebuah teknik data mining yaitu prediksi. Model prediksi ini memprediksi hasil dimasa depan berdasarkan catatan masa lalu yang diambil dari dari database (Aldallal \& Al-Moosa, 2018). Prediksi melibatkan beberapa variabel dalam mengumpulkan data untuk memprediksi nilai yang belum diketahui dari suatu variabel (Rao et al., 2017).

Data mining merupakan proses pencairan dan penggalian pengetahuan dari sejumlah data yang besar untuk menemukan sebuah pola. Teknik data mining yang sering digunakan yaitu asosiasi, klasifikasi, clustering, prediksi dan lainnya (George \& Hema, 2015). Algoritma data mining digunakan dalam penambangan data dan sangat bermanfaat di kalangan kesehatan.

Algoritma regresi linear terbagi menjadi dua yaitu simple regresi linear dan multiple regresi linear (Herwanto et al., 2019). Hubungan antara satu variabel dependen dengan satu variabel independen disebut dengan Simple regresi linear, sedangkan hubungan antara satu variabel dependen dengan dua atau lebih variabel independen disebut dengan multiple linear regression (Herwanto et al., 2019). Algoritma yang digunakan dalam penelitian ini yaitu multiple linear regression karena memiliki 8 atribut independen dan 1 atribut dependen. Tujuan dari penelitian ini yaitu keadaan kesehatan seseorang menderita diabetes atau tidak berdasarkan data yang didapatkan serta nilai root mean square error (RMSE) yang diperoleh dari pengujian cross validation dengan mengubah number of validation untuk melihat keakuratan metode.

\section{METODOLOGI PENELITIAN}

Cara yang digunakan untuk menyelesaikan masalah dalam penelitian ini dikatakan dengan sebagai metode penelitian.

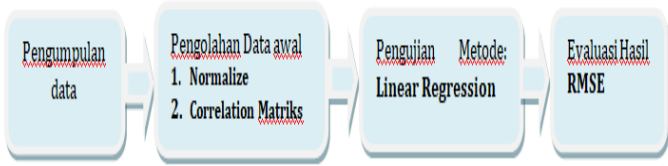

Sumber: (Hayuningtyas \& Sari, 2021)

Gambar 1. Metode Penelitian

Dalam penelitian ini metode penelitian yang digunakan dimulai dari :

\section{Pengumpulan Data}

Data yang digunakan didapat dari https://www.kaggle.com/kandij/diabetes-

dataset/code. Data ini terdiri dari 9 atribut terdiri dari 1 variabel dependen yaitu outcome sebagai nilai akhirnya yang diprediksikan, dan 8 atribut sebagai variabel independen yang mempengaruhi penyakit diabetes. Atribut data penelitian ini dapat dilihat pada tabel dibawah ini

Tabel 1. Atribut

\begin{tabular}{|ll|}
\hline \multicolumn{1}{|c|}{ Atribut } & \multicolumn{1}{c|}{ Keterangan } \\
Pregnancies & Berapa kali hamil \\
\hline Glucose & $\begin{array}{l}\text { Konsentrasi glukosa plasma } \\
\text { selama 2 jam }\end{array}$ \\
\hline Blood Pressure & $\begin{array}{l}\text { Tekanan darah diastolik (mm } \\
\text { Hg) }\end{array}$ \\
\hline Skin Thickness & Ketebalan kulit trisep (mm) \\
\hline Insulin & $\begin{array}{l}\text { Insulin serum selama 2 jam } \\
(\text { mu U/ml) }\end{array}$ \\
\hline BMI & $\begin{array}{l}\text { Index massa tubuh (berat } \\
\text { dalam kg/(tinggi dalam } \\
\left.\mathrm{m})^{\wedge} 2\right)\end{array}$ \\
\hline Diabetes $\quad$ Pedigree & Fungsi silsilah diabetes \\
Function & Usia (tahun) \\
\hline Age & Hasil \\
\hline Outcome & Menderita Diabetes \\
& $0:$ Tidak Menderita Diabetes \\
\hline
\end{tabular}

Sumber: (Hayuningtyas \& Sari, 2021)

\section{Pengolahan Data Awal}

Pengolahan data awal terdapat beberapa proses yaitu normalize dan Correlation matrix. Normalize digunakan untuk penskalaan nilai atribut dari sebuah data. Pada penelitian ini menggunakan normalize dengan metode range transformation yang nantinya nilai dari setiap atribut minimal 0 dan $\max 1$. Correlation matrix digunakan untuk membuat matriks korelasi antar atribut.

\section{Pengujian Metode}

Regresi merupakan suatu hubungan yang menentukan variabel terikat dengan variabel bebas (Prasetyo et al., 2021). Algoritma linear regression berganda merupakan algoritma yang memiliki variabel lebih dari satu (Gaol et al., 2019).

Variabel dependen (y) pada penelitian ini yaitu hasil akhir menderita diabetes atau tidak, sedangkan variabel independen adalah pregnancies, glucose, 
blood pressure, skin thickness, insulin, BMI, diabetes pedigree function, dan age.

Perhitungan multiple linear regression dapat dilihat di bawah ini (Herwanto et al., 2019):

$$
Y=a+a_{1} x_{1}+b_{2} x_{2}+\ldots \ldots+b_{n} x_{n}
$$

Dengan :

Y

$\mathrm{X}_{1}, \mathrm{X}_{2} \ldots \mathrm{X}_{\mathrm{n}}$

= Variabel dependen (nilai yang diprediksikan)

= Variabel independen

$b_{1}, b_{2} \ldots b_{n} \quad=$ Koefisien regresi

Untuk mengetahui pengaruh variabel independen dengan dependen dapat menggunakan uji koefisien. Koefisien bernilai 0 sampai dengan 1. Jika koefisien bernilai 0 maka tidak berpengaruh apa-apa, tetapi sebaliknya jika koefisien mendekati angka 1 maka semakin kuat pengaruhnya (Herwanto et al., 2019).

\section{Evaluasi Hasil}

Root mean square error (RMSE) merupakan akar kuadrat dari kuadrat kesalahan rata-rata yang dihasilkan dari perhitungan (Prasetyo et al., 2021). Jika hasil RMSE semakin rendah maka akan semakin baik hasil prediksinya.

RMSE $\frac{\sum_{\mathrm{i}}^{n}=\sqrt{6 y^{i}-y^{2}}}{n}$

Nilai RMSE yang rendah menunjukkan bahwa nilai yang dihasilkan suatu model perkiraan mendekati nilai aslinya. Sedangkan nilai RMSE semakin besar, maka keakuratan nilai yang dihasilkan semakin tidak akurat (Herwanto et al., 2019)

\section{HASIL DAN PEMBAHASAN}

\section{Pengumpulan Data}

Data yang digunakan sebanyak 786 data. Berikut adalah data diabetes dalam rapidminer.

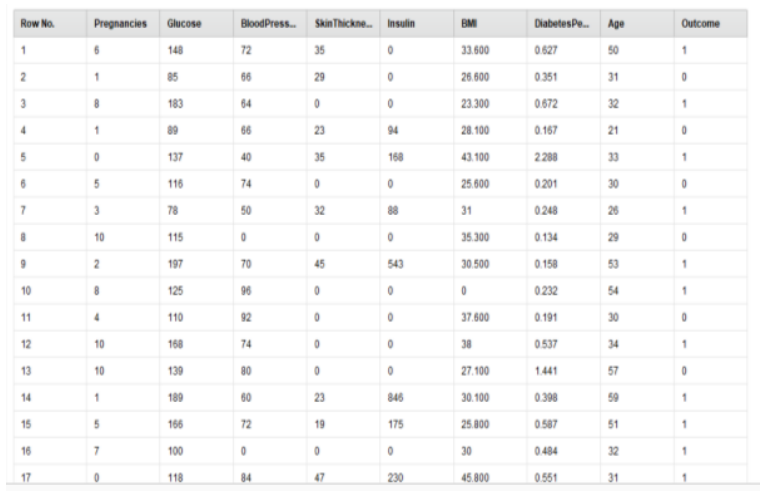

Sumber: (Hayuningtyas \& Sari, 2021)

Gambar 2. Data Awal

\section{Pengolahan data awal}

Tahapan pengolahan data awal dengan normalize dan correlation matrix. Berikut adalah hasil dari normalize dan correlation matrix.

\begin{tabular}{|c|c|c|c|c|c|c|}
\hline Nane & if Tse & Ulssing & Satstis & & & Filer $9 / 9$ at \\
\hline V Pregnancies & Reat & 0 & 0 & 1 & 0226 & \\
\hline$\checkmark$ Glucose & Real & 0 & 0 & 1 & 20600 & \\
\hline V BloodPressure & Real & 0 & $\begin{array}{l}\text { Int } \\
0\end{array}$ & 1 & 0.560 & \\
\hline$\checkmark$ SkinThickness & Real & 0 & int & 1 & 0207 & \\
\hline$\checkmark$ insulin & Real & 0 & in & 1 & 0004 & \\
\hline
\end{tabular}

Sumber: (Hayuningtyas \& Sari, 2021)

Gambar 3. Normalize

Pada gambar 2 terlihat bahwa nilai masing-masing atribut minimal 0 dan maksimal 1 .

\begin{tabular}{|c|c|c|c|c|c|c|c|c|c|}
\hline Antives & Prepenos & Chosese & alopersoser & sennichess & insilh & an & 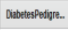 & 100 & Otitume \\
\hline Phyposs & 1 & 028 & 0141 & Ane & 9074 & 0418 & .004 & 0.54 & 0222 \\
\hline Gosist & ara & , & 0159 & 0067 & 0331 & 0221 & 0137 & 0224 & 0057 \\
\hline Bugesessus & 0141 & 0193 & 1 & 0207 & o0:9 & 0282 & 0041 & 0220 & 0055 \\
\hline Simflomss & 2002 & 0687 & 0228 & 1 & 0497 & 0.200 & Q144 & s.14 & 0015 \\
\hline nusun & 20074 & 0.311 & 0008 & 0.67 & 1 & 0.198 & 0.155 & 1006 & 0151 \\
\hline Bu & 0018 & 021 & 0228 & $0: 393$ & 0190 & 1 & 0,41 & $000 x$ & 0223 \\
\hline Distereagy. & 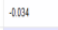 & ang & 00041 & 0.14 & 01015 & 0.141 & ' & 0084 & 274 \\
\hline 198 & 054 & 084 & 0220 & s.114 & $\$ 012$ & 0038 & 0034 & 1 & 0288 \\
\hline atrove & $0 \mathrm{~mm}$ & 0.57 & 0005 & 0005 & 0.131 & 020 & 0.74 & 0230 & , \\
\hline
\end{tabular}

Sumber: (Hayuningtyas \& Sari, 2021) Gambar 4. Correlation Matrix

Pada atribut outcome dijadikan sebagai label dengan menggunakan operator set role. Berikut adalah hasil dari menggunakan operator set role.

\begin{tabular}{|c|c|c|c|c|c|c|c|c|c|}
\hline \multicolumn{9}{|c|}{ 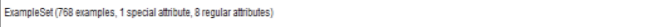 } & \multirow{2}{*}{ 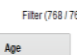 } \\
\hline Row No. & cutcame & Pregnanacios & Glucose & Bhoodpress. & SkkinThickne... & insuln & вм & Diatobsespen. & \\
\hline 1 & 1 & 0.353 & 0.74 & 0.590 & 0.354 & 0 & 0.501 & 0254 & 0.483 \\
\hline 2 & 0 & 0.059 & 0.227 & 0.541 & 02293 & 0 & 0.396 & 0.117 & 0.167 \\
\hline 3 & 1 & 0.471 & 0.920 & 0.225 & 0 & 0 & 0.347 & 0254 & 0.183 \\
\hline 4 & 0 & 0.069 & 0.447 & 0.541 & 0232 & 0.111 & 0.419 & 0.0085 & 0 \\
\hline 5 & 1 & 0 & 0.088 & 0.328 & 0.354 & 0.199 & 0.642 & 0.944 & 02200 \\
\hline 6 & 0 & 0.294 & 0.583 & 0.007 & 0 & 0 & 0.382 & 0.063 & 0.150 \\
\hline 7 & 1 & 0.176 & 0.392 & 0.410 & 0.223 & 0.104 & 0.462 & 0.073 & 0.083 \\
\hline 8 & 0 & 0.588 & 0.578 & 0 & 0 & 0 & 0.526 & 0.024 & 0.133 \\
\hline 9 & 1 & 0.118 & 0.990 & 0.574 & 0.455 & 0.642 & 0.455 & 0.0034 & 0.533 \\
\hline 10 & 1 & 0471 & 0.028 & 0.787 & 0 & 0 & 0 & 00065 & 0.550 \\
\hline 11 & 。 & 0225 & 0.553 & 0.754 & 0 & 0 & 0.560 & ouss & 0.150 \\
\hline 12 & 1 & 0.588 & 0.844 & 0.007 & 0 & 0 & 0.566 & 0.196 & 0217 \\
\hline 13 & 0 & 0.580 & 0.599 & 0.656 & 0 & 0 & 0.404 & 0.502 & 0.6000 \\
\hline 14 & 1 & 0.059 & 0.950 & 0.492 & 02322 & 1 & 0.449 & 0.197 & 0.0933 \\
\hline 15 & 1 & 0.224 & 0.834 & 0.590 & 0.922 & 0.207 & 0.385 & 0217 & 0.500 \\
\hline
\end{tabular}

Sumber: (Hayuningtyas \& Sari, 2021)

Gambar 5. Set Role

\section{Pengujian Metode}

Pada pengujian metode data menggunakan cross validation dengan mengubah number of validation dari 2 sampai dengan 7 untuk mendapatkan nilai RMSE yang paling rendah. Kemudian pengujian metode menggunakan multiple linear regression. 
Berikut adalah hasil dari pengujian dari metode.

\begin{tabular}{|c|c|c|c|c|c|c|c|c|c|c|}
\hline \multicolumn{9}{|c|}{ 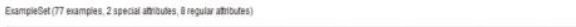 } & \multicolumn{2}{|c|}{ 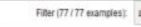 } \\
\hline Row ka. & atcome & prescace it & nopanoses & acouse & mosere. & senincase.- & main & $m$ & nowers. & so \\
\hline${ }^{24}$ & , & osea & 0.529 & 0825 & 0697 & 0152 & 0 & 0407 & oess & 2067 \\
\hline s & , & ass6 & 278 & онตร & 0572 & 0.045 & 0950 & 2572 & 0878 & 0208 \\
\hline is & , & orat & ossa & a7u & 2959 & 0005 & 0230 & asso & 0.34 & osso \\
\hline 32 & i & 0700 & 0 & ara & 。 & 0 & 0 & 0650 & 0200 & 0.10 \\
\hline s & , & esso & 0412 & oset & 0721 & 0.24 & 0379 & osso & 0309 & 031 \\
\hline s & 1 & 057 & 0059 & 0910 & 0.586 & 0903 & 025 & 0.508 & 01007 & 0203 \\
\hline 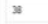 & 1 & 0656 & 0.539 & 0820 & ant & 0 & 0 & 2045 & 0000 & 0.678 \\
\hline$\pi$ & 1 & 0652 & Qeat & $2 \pi 4$ & 0.39 & 0.250 & . & oass & 9156 & 0.000 \\
\hline : & - & ossa & 0412 & atso & ost & oes & 0.004 & 0517 & $02 n$ & 0.350 \\
\hline 1 & , & osso & 0353 & 074 & 0.550 & 0.34 & 0 & 0.507 & 0224 & 0.43 \\
\hline 27 & 1 & 0008 & 0 & 00003 & 。 & 0 & 0 & OSAT & Q.935 & 0067 \\
\hline 2 & 1 & ans & 0059 & 0955 & 0.028 & 0.22 & , & OAds & 019 & 0639 \\
\hline$\pi$ & . & OE:50 & Q1110 & 2606 & 0 & 0 & 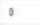 & 0.574 & 00000 & 0393 \\
\hline 21 & 1 & Q500 & a+11 & 0794 & Q7no & 0 & 0 & ear & QS10 & 0750 \\
\hline st & , & Q6002 & a.058 & Q2069 & 0.507 & 0 & . & Q58B & 20000 & 02313 \\
\hline & & & & 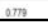 & & & & & & 0217 \\
\hline
\end{tabular}

Gambar 6. Multiple linear regression

Pada gambar 6 terlihat hasil prediksi dari data yang diolah. Dan menghasillan nilai koefisien dari setiap atribut.

\begin{tabular}{|l|l|}
\hline Attribute & Coefficient \\
\hline Pregnancies & 0.350 \\
\hline Glucose & 1.178 \\
\hline BloodPressure & -0.284 \\
\hline SkinThickness & 0.015 \\
\hline Insulin & -0.153 \\
\hline BMl & 0.889 \\
\hline DiabetesPedigreeFunc... & 0.345 \\
\hline Age & 0.157 \\
\hline
\end{tabular}

Sumber: (Hayuningtyas \& Sari, 2021)

Gambar 7. Koefisien dari Atribut

Koefisien relasi ini digunakan untuk mengukur kekuatan hubungan antara beberapa variabel. Untuk melihat hubungan koefisien relasi dapat menggunakan analisa korelasi. Korelasi dapat bernilai positif, negative, atau tidak ada korelasi.

Korelasi positif dimana variabel bebas mengikat ke variabel tak bebas, nilai dari korelasi positif mendekati angka 1 atau 1. Sedangkan korelasi negative dimana variabel bebas mengikat ke variabel tak bebas, nilai dari korelasi negative mendekati angka -1 atau -1 . Tidak ada korelasi bernilai 0 .

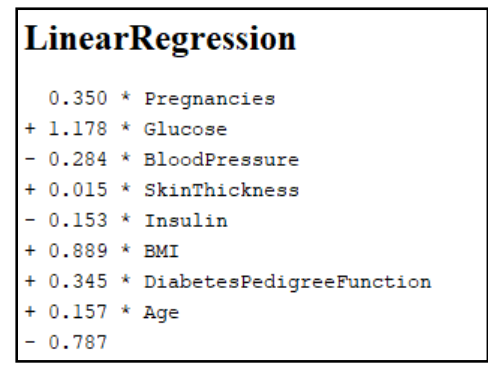

Sumber: (Hayuningtyas \& Sari, 2021)

Gambar 8. Linear Regression
Dari hasil pengujian metode didapatkan persamaan dapat dilihat dibawah ini.

$\mathrm{Y}=$ outcome

$\mathrm{X}_{1}=$ Pregnancies

$\mathrm{X}_{2}=$ Glucose

$\mathrm{X}_{3}=$ Blood Pressure

$\mathrm{X}_{4}=$ Skin Thickness

$\mathrm{X}_{5}=$ Insulin

$\mathrm{X}_{6}=\mathrm{BMI}$

$\mathrm{X}_{7}=$ Diabetes Pedigree Function

$\mathrm{X}_{8}=$ Age

$\mathrm{Y}=\left(0.350 * \mathrm{X}_{1}\right)+\left(1.178 * \mathrm{X}_{2}\right)-\left(0.284 * \mathrm{X}_{3}\right)+$ $\left(0.015 * \mathrm{X}_{4}\right)-\left(0.153 * \mathrm{X}_{5}\right)+\left(0.889 * \mathrm{X}_{6}\right)+(0.345 *$

$\left.X_{7}\right)+\left(0.157 * X_{8}\right)-0.787$

\section{Evaluasi Hasil}

Dari hasil pengujian metode ini, menghasilkan nilai root mean square error (RMSE). Nilai root mean square error yang diperoleh dapat dilihat pada tabel dibawah ini.

Tabel 2. Hasil root mean square error

\begin{tabular}{|cc|}
$\begin{array}{c}\text { Number of } \\
\text { Validation }\end{array}$ & Nilai RSME \\
\hline $\mathbf{2}$ & 0.408 \\
\hline $\mathbf{3}$ & 0.407 \\
\hline $\mathbf{4}$ & 0.404 \\
\hline $\mathbf{5}$ & 0.405 \\
\hline $\mathbf{6}$ & 0.405 \\
\hline $\mathbf{7}$ & 0.403 \\
\hline $\mathbf{8}$ & 0.404 \\
\hline $\mathbf{9}$ & 0.405 \\
\hline
\end{tabular}

Sumber: (Hayuningtyas \& Sari, 2021)

\section{KESIMPULAN}

Penelitian ini membahas tentang penerapan multiple linear regression terhadap penyakit diabetes. Data yang digunakan sebanyak 786 data yang terdiri dari 1 atribut dependen dan 8 atribut independen yang menghasilkan persamaan.

Dari hasil percobaan cross validation dengan mengubah number of validation dari 2 sampai dengan 9 menghasil nilai root mean square error terendah di number of validation 7 dengan nilai root mean square error 0.403. Dari hasil RMSE ini menunjukkan bahwa nilai dari model perkiraan yang dihasilkan mendekati akurat.

\section{REFERENSI}

Aldallal, A., \& Al-Moosa, A. A. A. (2018). Using Data Mining Techniques to Predict Diabetes and Heart Diseases. 2018 4th International Conference on Frontiers of Signal Processing, ICFSP 2018, September, 150-154. https://doi.org/10.1109/ICFSP.2018.8552051 
Baiju, B. V., \& Aravindhar, D. J. (2019). Disease Influence Measure Based Diabetic Prediction with Medical Data Set Using Data Mining. Proceedings of 1st International Conference on Innovations in Information and Communication Technology, ICIICT 2019, 16. https://doi.org/10.1109/ICIICT1.2019.874145 2

Gaol, I. L. L., Sinurat, S., \& Siagian, E. R. (2019). Implementasi Data Mining Dengan Metode Regresi Linear Berganda Untuk Memprediksi Data Persediaan Buku Pada Pt. Yudhistira Ghalia Indonesia Area Sumatera Utara. KOMIK (Konferensi Nasional Teknologi Informasi Dan Komputer), 3(1), 130-133. https://doi.org/10.30865/komik.v3i1.1579

George, T., \& Hema, A. (2015). A Survey On Diabetes And Heart Disease Prediction Using Daata Mining Techniques. International Journal of Applied Engineering Research, 10(55), 2786-2789.

Hayuningtyas, R. Y., \& Sari, R. (2021). Laporan Akhir: Penelitian Implementasi Data Mining Dengan Algoritma Multiple Linear Regression Untuk Memprediksi Penyakit Diabetes.

Herwanto, H. W., Widiyaningtyas, T., \& Indriana, P. (2019). Penerapan Algoritme Linear Regression untuk Prediksi Hasil Panen Tanaman Padi. Jurnal Nasional Teknik Elektro Dan Teknologi Informasi (JNTETI), 8(4), 364. https://doi.org/10.22146/jnteti.v8i4.537

Islam, M. M. F., Ferdousi, R., Rahman, S., \& Bushra, H. Y. (2019). Likelihood Prediction of Diabetes at Early Stage Using Data Mining Techniques. In Computer Vision and Machine Intelligence in Medical Image Analysis.

Lindungi Keluarga Dari Diabetes - Direktorat P2PTM. (n.d.). Retrieved October 18, 2021, from http://p2ptm.kemkes.go.id/post/lindungikeluarga-dari-diabetes

Prasetyo, V. R., Lazuardi, H., Mulyono, A. A., \& Lauw, C. (2021). Penerapan Aplikasi RapidMiner Untuk Prediksi Nilai Tukar Rupiah Terhadap US Dollar Dengan Metode Regresi Linier. Jurnal Nasional Teknologi Dan Sistem Informasi, 7(1), 8-17. https://doi.org/10.25077/teknosi.v7i1.2021.817

Putri, S. U., Irawan, E., \& Rizky, F. (2021). Implementasi Data Mining Untuk Prediksi Penyakit Diabetes Dengan Algoritma C.45. KESATRIA( Jurnal Penerapan Sistem Informasi Dan Manajemen, 2(1), 39-46.

Rahimloo, P., \& Jafarian, A. (2016). Prediction of Diabetes by Using Artificial Neural Network, Logistic Regression Statistical Model and
Combination of Them. Bulletin de La Société Royale Des Sciences de Liège, 85, 1148-1164. https://doi.org/10.25518/0037-9565.5938

Rao, K., Yellaswamy, K., \& Chandu, Y. (2017). A comparative study of heart disease predictionusing classification techniques in data mining. October 2015. 